\title{
İnşaat mühendislerinin kariyer planlamaları üzerine bir araştırma
}

\author{
Fehmi Çivíci* \\ Balıkesir Üniversitesi Mühendislik Fakültesi, İnşaat Mühendisliği Bölümü, Çağış kampüsü, Balıkesir \\ Geliş Tarihi (Received Date): 11.01.2021 \\ Kabul Tarihi (Accepted Date): 23.05.2021
}

$\ddot{O} \mathbf{z}$

Fransızcadan dilimize geçen kariyer kelimesi; bir hedefe varmak için yürünen yol, başlangıç ve bitiş noktaları arasındaki süreçtir. Bir başka deyişle; kişinin kendisini gelecekte nerede görmek istediğinin planlamasını yapmasıdır. Belirlenen hedefe ulaşma söz konusu sürecin doğru ve etkin bir şekilde yönetilmesiyle mümkündür. Bu olgu kariyer planlaması olarak bilinir. Mühendislik alanında çalışacak bireylerin iyi eğitim almış, iyi dil bilen, vizyonu yüksek ve ekip çalışmasına yatkın olma yeteneğine sahip olması gerekir. Çalışmada, BAUN, Mühendislik Fakültesi, Inş̧aat Mühendisliği Bölümünden mezun olup çalışma hayatına atılan iki yüz elli bireye Covid-19 pandemi süreci koşullarına bağll olarak e-posta ile anket formu gönderilmiştir. Demoğrafik yapı özellikleri çalışmada verilmiş yüz mezun katılımcı anketi cevaplayarak geri dönüş yapmıştır. Mezunların kariyer planlamalarındaki sahip oldukları kariyer bilincinin ölçülmesi ve bu planı etkileyen etmenlerin hangi oranda yer aldığ belirlenip, mezunların gelecekte nerede olmak istersiniz sorusuna verdikleri cevapların ışığında değerlendirilmesi yapılmıştır. Elde edilen verilere dayanarak; inşaat mühendisliği bölümü eğitimi, eğitimin sektörde uygulamadaki sorunları çözmedeki verimliliği, katılımclların kariyer bilinçleri ve kariyer planlamalarındaki etkenler değerlendirilmiştir. Katılımcıların anket sorularına verdikleri cevaplardan elde edilen bulgular arasında; mesleki alanda kullanılan yazılımları öğrenme çabalarının büyük oranda kendi gayretleri ile olduğu, dil eğitiminin kariyerlerine katkısının önemi, meslek seçimlerinde önceden inşaat sektörü hakkında bilgi sahibi oldukları, mesleki gelişimi ile hedefledikleri kariyer basamaklarını aşacakları örnekleri göze çarpmaktadır. Çalışmanın İşaat Mühendisliği Bölümlerinde hem okumakta olan öğrenciler hem de mezun durumundaki bireylerde kariyer bilinci farkındalığının oluşturulması ve kariyerlerini etkin bir şekilde planlamalarında/kariyer yönetiminde olumlu yönde yarar sağlayacă̆ı düşünülmektedir.

Anahtar kelimeler: Kariyer, kariyer planlaması, inşaat mühendisliğinde kariyer.

\footnotetext{
* Fehmi ÇivíCI, fcivici@balikesir.edu.tr, http://orcid.org/0000-0001-9957-1628
} 


\title{
A research on the career planning of civil engineers
}

\begin{abstract}
The word career in French language; the path to reach a destination is the process between the start and end points. In other words; is to plan where the person wants to see him in the future. Achieving the specified goal is possible by managing the process in question correctly and effectively. This phenomenon is known as career planning. Individuals who will work in the field of engineering must have the ability to be well educated, fluent in the language, high vision and teamwork. In the study, a questionnaire form was sent by e-mail to two hundred and fifty individuals who graduated from BAUN, Faculty of Engineering, Department of Civil Engineering and started working life, depending on the conditions of the Covid-19 pandemic process. One hundred graduates, whose demographic structure features were given in the study, responded by answering the questionnaire. The career awareness of the graduates in their career planning was measured and the factors affecting this plan were determined and evaluated in the light of the answers given by the graduates to the question of where would you like to be in the future. Among the findings obtained from the answers given by the participants to the questionnaire questions; There are examples that the efforts to learn the software used in the professional field are largely through their own efforts, the importance of language education's contribution to their careers, they have knowledge about the construction sector in their career choices, and they will surpass the career steps they have targeted with their professional development. It is believed that the Civil Engineering Departments of the study will positively benefit both in the development of career awareness and career planning / career management for both graduate candidates and graduates.
\end{abstract}

Keywords: Career, career planning, career in civil engineering.

\section{Giriş}

İnsanın geleceği ile alacağı kararlardan en önemlisi kariyeri ile ilgili olanlardır. İnsanlar, iş doyumu sağlayabilecekleri, başarılı olacakları ve onları mutlu edeceğine inandıkları kariyer kararlarını okuldan işe geçiş dönemi olan yirmili yaşlarda vermektedirler [1]. Bu süreçte kariyer kararı yetkinliği yüksek olan kişilerin süreci yönetme başarılarının daha yüksek olduğu ve doğru kariyer seçimi yapabildikleri bilinmektedir.

Gelişen ekonomi ölçeğinde nitelikli çalışanlar ön plandadır. Bunu sağlayan; bu kişilerin kendilerine ait plan yapmaları ve bu plan doğrultusunda kendilerini geliştirmeleridir. Bir başka deyişle; kariyerlerine doğru yön vermeleridir.

Kariyer; insanların iş ve yaşam hedefleri tarafından yönlendirilen ve içinde çalıştıkları kurum tarafından yönetilen gelişim sürecindeki davranışları, tutumları ve duyguları içeren yaşam boyu süren bir çabadır [2]. Kariyer planlaması ve seçimi genelde üniversite mezuniyet aşamasında gündeme gelir. Ancak öğrenciler meslek seçimlerinde kariyerlerini hatta kariyer planlarını düşünmezler. Çoğunlukla kariyer planlaması mezuniyetten sonra başlar. Öğrencilerin kariyer planlama sürecinde birçok faktör 
belirleyici olur. Bu faktörler; aile, yaş, cinsiyet, kişisel özellikler, yetenekler, yasal faktörler, sosyal faktörler ve eğitim kurumlarının etkisidir [2]. Öğrencilerin kariyer planlama sürecinde karşılaşabilecekleri problemleri inceleyen çalışma azdır. $\mathrm{Bu}$ çalışma ile; inşaat mühendisliği bölümünden mezun bireylerin meslek seçimlerinde hangi unsurların etkisinin olduğu, ilgi alanlarının kariyer gelişimlerinin hangi dönemlerinde ön plana çıktığı, hedefi ile şu an bulundukları konum arasındaki mesafenin boyutu ve bu hedefe ulaşırken ne tür izler bırakmak istedikleri ortaya konulmuştur. Bu çalışmanın, halihazırda öğrenimlerine devam eden öğrencilerin kariyer planlaması farkındalıklarını arttırmak ve mezun durumundaki bireylerin bulundukları pozisyonlarına göre kariyer planlama hedefleri açısından bir değerlendirme yapma olanağ1 sağlayacağı düşünülmektedir.

\section{2. İnşaat mühendisliği eğitimi alan bireylerin kariyer planlama süreçleri ve etki eden faktörler}

İnşaat Mühendisliği; yollar, köprüler, kanallar, barajlar ve binalar gibi işlerde dahil olmak üzere fiziksel ve doğal olarak inşa edilmiş ortamın tasarımı, yapımı ve bakımı ile ilgilenen profesyonel bir meslek disiplinidir [3,4]. İnşaat sektörü; çok katılımcılı, dış çevreyle bağlantılı, insan odaklı ve ülke ekonomisine doğrudan katkı yapan lokomotif bir faaliyet alanıdır [5]. İnşaat mühendisliği birçok alt disiplini bulundurmakla birlikte sektörel alanı oldukça geniştir. İnşaat sektöründeki yoğun iş imkanı, her yıl pek çok öğrencinin inşaat mühendisliği bölümünü seçmesinde önemli rol oynamaktadır[6].

Orijini Eski Mısır İndus vadisi uygarlığı ve Mezopotamya'da insanların göçebe yaşamdan vazgeçerek barınma ihtiyaçlarını karşılamak adına barınakların yapımına dayanmaktadır [7]. Sonrasında Mısır'da Piramitlerin yapımıyla devam eden süreç teknoloji ve malzeme bilimindeki gelişmeler doğrultusunda günümüzde gökdelenlerin, su altı tüp yapıların, barajların, otoyolların, nükleer santrallerin inşası ile altın çağını yaşamaktadır. Bu süreçte iyi kariyerli inşaat mühendislerinin aldığı rol önemlidir. Bu projelerde görev almalarını destekleyen; aldıkları eğitimin yeterliliği ile birlikte kariyerlerini iyi yönetebilmeleridir.

İnşaat Mühendisliği Eğitimi; ABD'de 1800'lü yıllarda kolejde başlamış daha sonra ilk mezuniyet derecesi 1835 yılında Rensselaer Politeknik Enstitüsü tarafından verilmiştir [8]. Ülkemizdeki varlığı ise; 1727 yılında Damat İbrahim Paşa tarafından açılan İTÜ İnşaat Fakültesinin başlangıcı olarak kabul edilen Humbarhane kurumu ile başlar [9]. Bugün inşaat mühendisliği bölümleri, 110' u devlet, 102'si vakıf ve 7'si Kuzey Kıbrıs Türk Cumhuriyet'inde olmak üzere üniversitelerimizde örgün ve ikinci öğretim vb. programlarda eğitim ve öğretim hizmeti vermektedir [10]. Eğitim programlarının çıktısı olan mezunların sayıca fazlalığı istihdam problemlerini doğurmaktadır. $\mathrm{Bu}$ durumda; öğrencilik döneminde alınan eğitimin yeterliliği ve kariyer planlamasının doğru yapılması önemli etken olarak karşımıza çıkmaktadır. Bir başka açıdan söylenmek istenirse; eğitim aşamasında kariyer basamaklarını etkin planlayan mezunlar istihdam durumunda avantajlı olabilmektedirler. Peki doğru kariyer planlaması nasıl yapılır ve kariyer planlamasında karşılaşabileceğimiz engeller nelerdir? Kariyerin iki temel boyutu vardır; ilki kariyer planı yapacak bireyin bunu özümsemesi; diğeri iş ve çalışma hayatında yerini belirleme, ileride nerede olmak isteyeceğini planlamasıdır. Kariyer planlama aslında bir süreçtir. $\mathrm{Bu}$ planlama eğitimini bitiren bireyin işe başlangıç dönemi sonrasında bağımsız davranabileceği yeterli deneyime sahip olması, sorumluluk 
üstlenmesi, iş hayatında yükselmesi ve yaşa bağlı olarak geri çekilme ile birlikte emeklilik dönemini kapsar [11]. Bu süreçte bölüm mezunlarının yaşayabileceği temel sorunlara bağlı kariyer planlarını etkileyen etmenler; okulda almış oldukları eğitimin sektördeki karşılığının yetersizliği, inşaat mühendisliği eğitimi veren fakülte sayısının fazlalığı doğrultusunda fazla mezun sayısı, eğitimci kişilerin/akademisyenlerin yeterliliği, mesleki örgütsüzlük, yabancı dil durumu, düşük ücretli iş veren vizyonsuz şirketler ve kendi özgüvenleri şeklinde ifade edilebilir $[6,12]$.

\section{Araştırma yöntemi}

Mezunların kariyer planlamalarına yönelik verilerin toplanmasında anket yöntemi kullanılmıştır. Anket en genel tanımıyla cevaplandırıcının daha önce belirlenmiş bir sıralamada ve yapıda oluşturulan sorulara karşılık vermesiyle veri elde etme yöntemi olarak tanımlanabilir [13]. Bu çerçevede yapılmış olan çalışmalar; Janseen ve Chandler 'in [14] kariyer planlaması ile ilgili çalışması, İMO İnşaat Mühendisleri Eğitim Kurulu tarafından hazırlanan rapor [15] ve YTÜ İnşaat Mühendisliği Bölümü Mezun Anketi [16] dir. Bu kaynaklardan yararlanılarak soruların ve demografik bilgilerin yer aldığ1 anket formu geliştirilmiştir. Bu form Üniversitemiz etik kurulu onayı alınarak örneklemi temsil eden hemen ulaşılabilen \%10 luk bir mezun grubu üzerinde uygulanmıştır. Daha sonra soruların anlaşılır olup olmadığı değerlendirilmesi yapılarak sanal ortamda eposta yoluyla mezunlara ulaşılmıştır. Ankete katılıp geri dönüş yapan 100 katılımcı olmuştur. Katılımcıların demografik bilgileri tablo 1'de verilmiştir. Anket formu büyük çoğunluğu açık uçlu sorulardan oluşan 30 sorudan oluşmaktadır. Anket soruları hazırlanmadan önce literatür gözden geçirilerek katılımcıların profesyonel yaşamdaki donanımlarına ilişkin belirlenen yedi kriter tablo 2'de verilmiştir. Çalışmada, anket sorularının tamamını vermek yerine, soruları en iyi temsil eden belirlenmiş kriterler çatısında cevaplar değerlendirilmiştir.

Tablo 1. Katılımciların demografik yapısı.

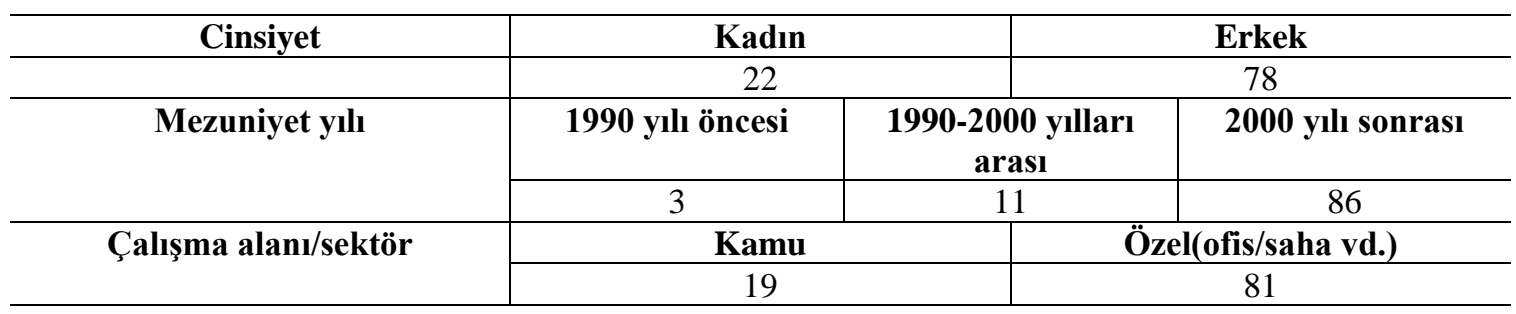

Tablo 2. Çalışmada kullanılan kriterler.

\begin{tabular}{c|l}
\hline Kriter no & \multicolumn{1}{c}{ Kriter tanımı } \\
\hline 1 & $\begin{array}{l}\text { Meslek icrasında kullanılan bilgisayar yazılımlarının hangi oranda olduğu, bu yazılımları } \\
\text { nasıl öğrendikleri }\end{array}$ \\
\hline 2 & Yabancı dilin meslekteki önemi, mevcut dil seviyelerini nasıl elde ettikleri \\
\hline 3 & Mezun olmak için şart olan büro/şantiye stajlarının meslek hayatına katkıları \\
\hline 4 & Almış oldukları mühendislik eğitiminin meslek icrası sahadaki yeterliliği \\
\hline 5 & $\begin{array}{l}\text { Son yıllarda üniversite öğrencileri arasında tercih belirlenmesinde inşaat mühendisliği } \\
\text { bölümünün popülerliği ve kendilerinin bu eğitimi seçmeden önce farkındalıkları, bu } \\
\text { eğitime yönlendirilmeleri }\end{array}$ \\
\hline 6 & $\begin{array}{l}\text { Kendilerini geliştirmek için kullandıkları yöntemler; seminer vb etkinliklere katılma, } \\
\text { mesleki yayınları takip etme, mesleki bir konuda eğitim desteği }\end{array}$ \\
\hline 7 & $\begin{array}{l}\text { Mezunların mevcut pozisyonlarının değerlendirilmesi, hedefleri ve bu hedeflere ulaşmak } \\
\text { için kullandıkları yöntemler }\end{array}$ \\
\hline
\end{tabular}




\section{Bulgular}

Katılımcıların anket sorularına verdikleri cevaplar belirtilen yedi kriter açısından incelenmiştir.

Katılımcılara, kullanmakta olduğunuz mesleki bilgisayar yazılımlarını nasıl öğrendiniz? sorusunun cevabı olarak katılımcılardan 60'ı kendi çabasıyla, 23'ü çalıştığ yerde aldığ 1 destek ile, 8'i özel kurslara giderek, 9'u ise fakülte eğitimi sırasında öğrendiklerini belirtmişlerdir (Şekil1). Bu soruyla ilişkili olarak katılımcılar bilgisayar yazılımlarını metraj/keşif, proje çizimi ve hak ediş işlerinde yoğun olarak kullandıklarını ifade etmişlerdir.

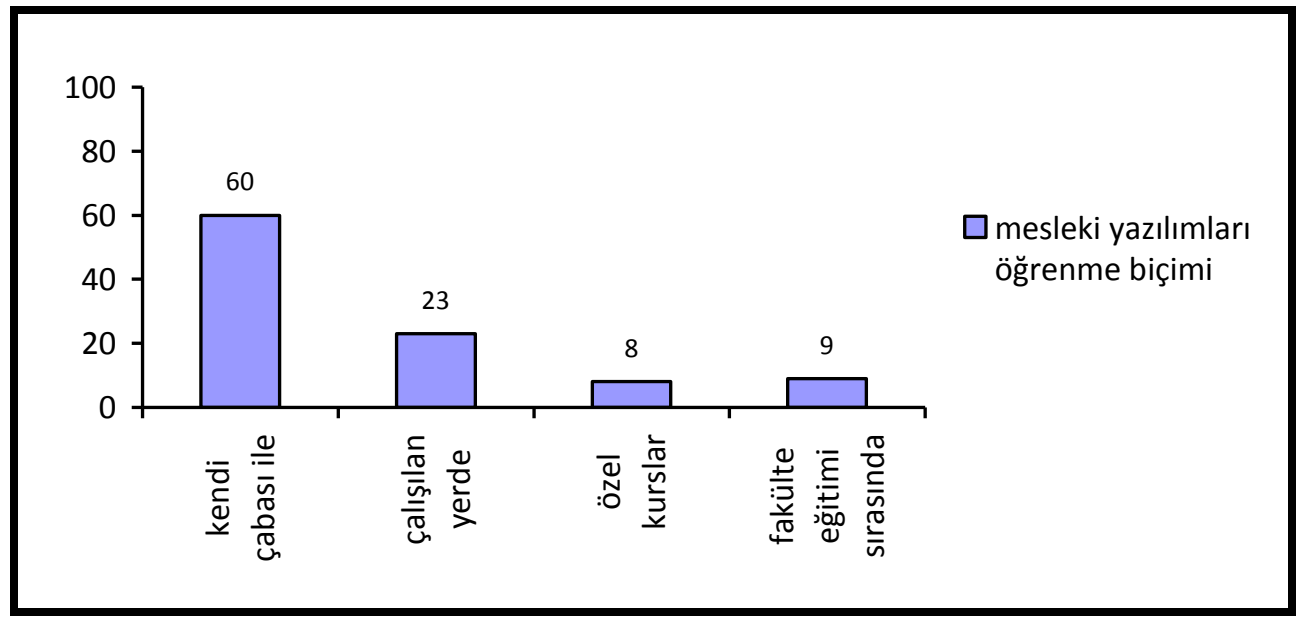

Şekil 1. Katılımcıların mühendislik yazılımlarını öğrenme yolları.

Katılımcılara hangi dil eğitimi aldıkları, almış oldukları dil eğitiminin mesleki katkısı ve inşaat mühendisliği eğitiminde yabancı dilin yeri konularında vermiş oldukları cevaplardan; büyük bir çoğunluğun İngilizce, Almanca dil eğitimi aldıkları görülmüştür. Bununla birlikte yurtdışı iş imkanları sebebiyle Rusça, Arapça dil eğitimi alanlar da olmuştur. Almış oldukları dil eğitiminin meslek icrasındaki katkısı olarak \%60 1 olumlu, \%40 1 olumsuz görüş vermişlerdir. Olumlu görüş verenler genelde; yabanc1 partnerler ile iletişimde, yabancı mesleki dergilerin takibinde ve lisansüstü eğitimleri sırasında faydalarını gördüklerini ifade etmişlerdir. İnşaat mühendisliği eğitiminde dilin yeri nedir? Sorusunun cevabı olarak; katılımcıların \% 65'i eğitimin ana dilde olması, \% 35 'i ise yabancı dilde eğitim verilmeli demektedir. Ayrıca sadece meslek dersleri yabancı dilde verilsin ve sadece lisansüstü eğitim yabancı dilde olsun şeklinde görüşlerde mevcuttur.

Öğrencilerin aldıkları teorik eğitiminin sahadaki karşıllğını gördükleri büro/şantiye stajlarının meslek hayatında katkısı olmuş mudur? şeklindeki soruya cevaben; \% 90'1 evet demiştir. İnşaat mühendisliği bölümünde 30 ar iş günü büro ve şantiye stajları zorunludur. Ayrıca stajlar meslek ile ilgili ilk tanışma alanlarıdır. Stajlar; adayın elde ettiği tecrübe ile sektörün hangi alanında çalışmak isteyeceğine karar vereceği; bir anlamda kariyer planlamasının bir evresini oluşturmaktadır. İş ortamı, işveren aktörlerini tanıma; mezuniyet sonrası istihdam açısından da olumlu bir süreçtir. Hatta katılımcıların birçoğu mezuniyet sonrası staj yaptıkları yerde çalışmaya başlamış olduklarını ifade etmişlerdir. Çok az katılımcının stajların verimli olmadığını 
düşünmesi; araştırılmadan yanlış staj yeri seçiminden ve stajda sürekliliğin sağlanamamasından kaynaklandığg söylenebilir.

Katılımcıların almış oldukları mühendislik eğitiminin sahadaki karşılığı yeterli mi? ve eğitimin eksiklikleri nelerdir? soruları sorulmuştur. Katılımcıların \%27 si teorik eğitimin uygulama da karşılığının yetmediğini, \%21 i Yasa ve yönetmeliklerin yeterince anlatılmadığını ve \%22 si güncel mesleki bilgisayar yazılımlarının anlatılmadığını belirtmiştir. İnşaat mühendisliği bölümleri son yıllarda artan kontenjanları ile dikkat çekmektedir. Kontenjan planlaması yapılırken fiziki imkanlar, öğretim üyesi sayısı, laboratuvar şartları vb. eğitimi doğrudan etkileyen faktörler dikkate alınmalıdır. Artan öğrenci sayısına bağlı olarak bölüm yeterlilikleri aynı oranda iyileştirilememektedir. $\mathrm{Bu}$ bağlamda bölümlerin akkreditasyon süreçlerinde de yeterlilikleri, yetenekleri ve mezunların kazanımları çok tartışılmaktadır.

Lisans eğitimini tamamlamak mühendislik yetki ve sorumluluklarını kullanmak için yeterli midir? Bu konudaki önerileri istenmiştir. Katılımcıların \%88 si yeterli olmadığını söylemiştir. Katılımcıların; \%21 i mezunların asgari deneyim elde edinceye kadar kısıtlı yetki ile çalışması, $\% 45$ i belirli bir süre stajer mühendis olarak çalışması ve $\% 34$ ü belirli bir süre sonunda elde edilen deneyim sonrası sınava girilerek yetkin mühendis ünvanının kazanılması şeklinde önerilerini sunmaktadırlar (Şekil 2). Ayrıca inşaat mühendisliği eğitim programlarının kalitesinin arttırılması ve kişisel gelişimlerin iyileştirilmesi ifade edilmektedir.

Adayların büyük çoğunluğu (\%90) özel sektörde, diğerleri ise kendi işini kurmuş durumdadır. Ayrıca mezunların çok az oranı inşaat mühendisliği alanı ile birlikte ticaret amacıyla başka bir alanda faaliyet sürdürmektedir.

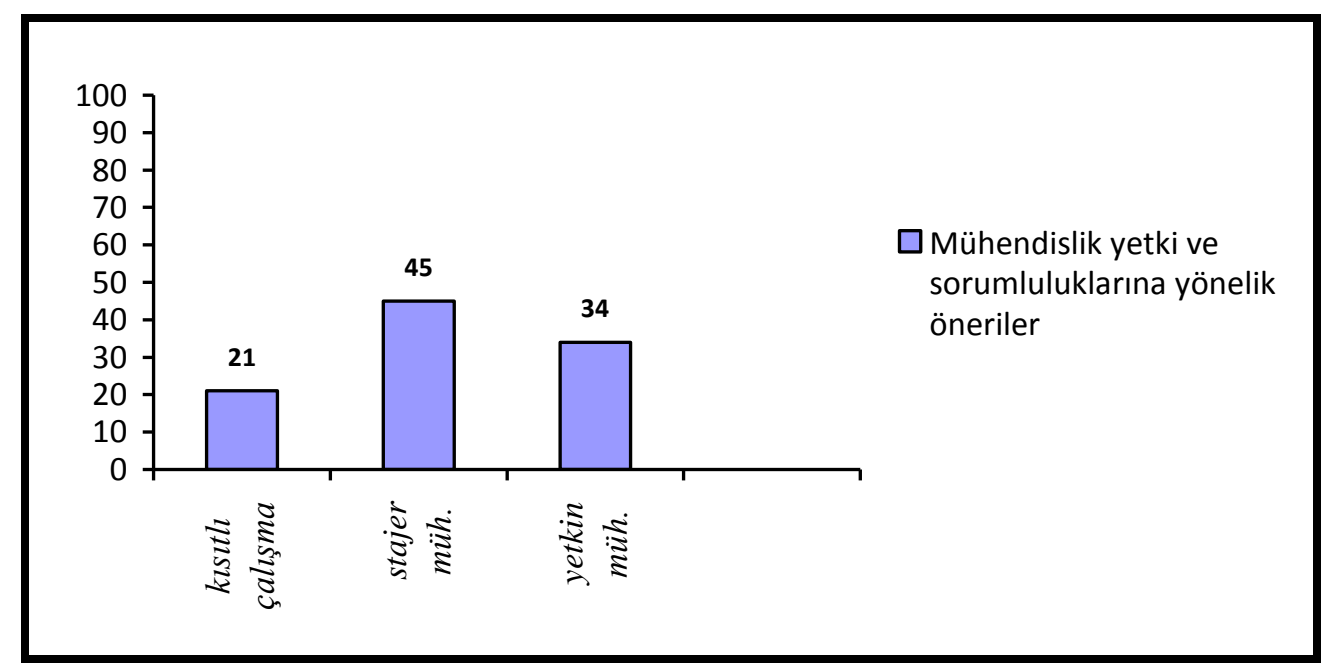

Şekil 2. Mühendislik yetki ve sorumluluklarının mezuniyet sonrası hemen kullanımı konusundaki öneriler.

Mezunların kariyer planlamaları sürecinin başlangıcı üniversite sınavına hazırlık aşamasındaki meslek seçimleri evresidir. Bu konuyla ilgili olarak inşaat mühendisliği eğitimini tercih sebepleri sorulmuştur. Katılımcıların \%7 si fizik ve matematik alanına yatkınlıklarının, $\% 23$ ü popüler bir meslek dalı olmasının, \%26 s1 aileden gelen meslek geleneğinin, \%38 i mesleğe karşı olan ilgilerinin ve \%6 s1 üniversite sıralamasının tercihlerinde etki ettiğini ifade etmiştir (Şekil3). Bu soruyla bağlantılı olarak meslek 
seçiminde aile ve çevrenizin yönlendirmesi var mıdır? sorusuna cevaben \% 48'i evet demiştir.

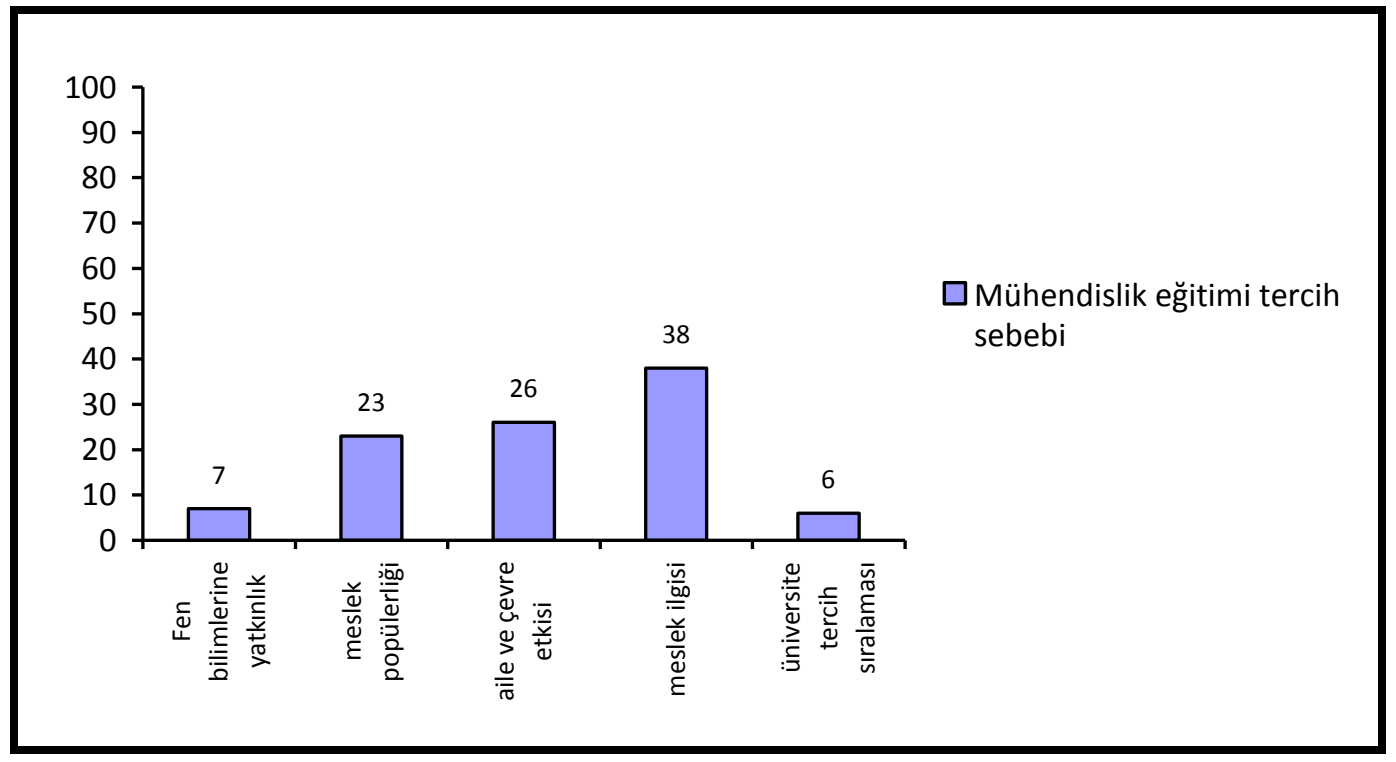

Şekil 3. Mühendislik eğitimi tercih sebebi.

Katılımcılara inşaat mühendisliği dışında farklı bir alanda eğitim görme isteğiniz var mıdı? Var ise; alan adı sorulmuştur. Mezunların \%62 si hayır cevabı vermiştir. Evet diyenlerin \%9'u mimarlık, \%6'sı farklı mühendislik alanları, \%3'ü tıp şeklinde oranlanmıştır. Büyük çoğunluğun kariyer planlama sürecinin şekillenmesinde inşaat mühendisliği yönünde kararlı olduklarını görmekteyiz. Bununla birlikte inşaat mühendisliği eğitimine başlamadan önce meslek hakkında bilgi durumları sorulmuştur. Alınan cevapların dökümü grafikte verilmiştir. (Şekil 4) katılımcıların meslek öncesi meslek hakkındaki bilgileri orta ve yeterli cevapları birlikte düşünülerek $\% 53$ dür. Katılımcıların meslek hakkındaki önceki ilgileri kariyer planlamalarında rol oynamıştır. Katılımcıların bu soruya verdikleri cevaplardan; mezuniyet sonrasi meslek seçimlerinden ve meslek icrasından memnun olduklarını anlamaktayız.

Katılımcılara üniversite sınavları tercih aşamasında inşaat mühendisliği mesleğinin avantajları olarak neleri gördünüz? sorusu sorulmuştur. Alınan cevaplar doğrultusunda katılımcıların inşaat sektörünün lokomotif bir sektör olduğu, mezuniyet sonrası iş hacminin büyüklüğüne bağlı istihdam olanakları șeklinde cevaplandıranlar \%72 oranındadır. $\% 18$ i bu meslekten elde edebilecekleri kazanç miktarının önemli olduğunu ifade etmişlerdir. \%10 luk kısım aile yönlendirmesi ve tercih formundaki kontenjan miktarı şeklinde görüş belirtmişlerdir (Şekil 5). 


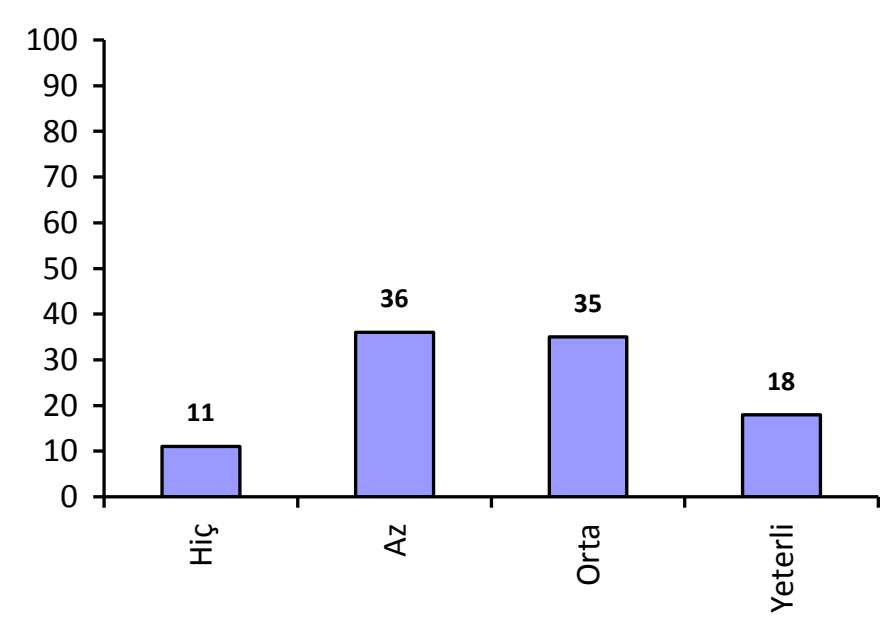

$\square$ Eğitim öncesinde meslek hakkındaki bilgi durumu

Şekil 4. Mühendislik eğitimi öncesinde meslek hakkındaki bilgi durumu.

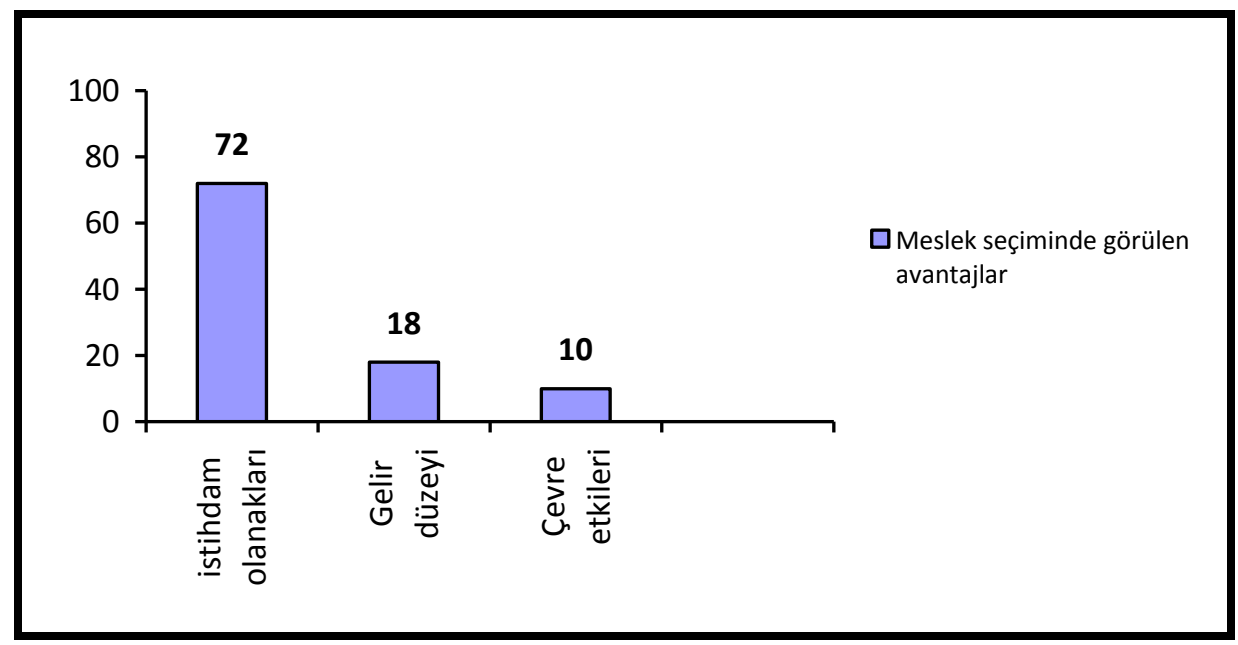

Şekil 5. Meslek seçiminde görülen avantajlar.

Katılımcılara yöneltilen bir başka soru ise; kariyer planlamalarının bir aşaması olan ileride kendinizi nerede görmek istiyorsunuz dur? Katılımcıların \%71'i meslekte kendini geliştirmek, \%12'si kurumsal bir ofiste çalışmak, \%11'i ticaret yapmak, \%2'si devlet/kamuda çalışmak, \%2'si siyaset alanında olmak, \%2'side mühendislik yapmayacağım şeklinde cevap vermiştir(Şekil 6).

Katılımcıların büyük çoğunluğu lisansüstü eğitim desteği ile sahada tecrübeli proje mühendisleri olmak istediklerini belirtmişlerdir. Mesleki gelişim, farklı projelerde görev alma, kurumsal ofislerin yeteneklerinin, kariyerlerine olumlu etki edeceklerini düşünmektedirler. 


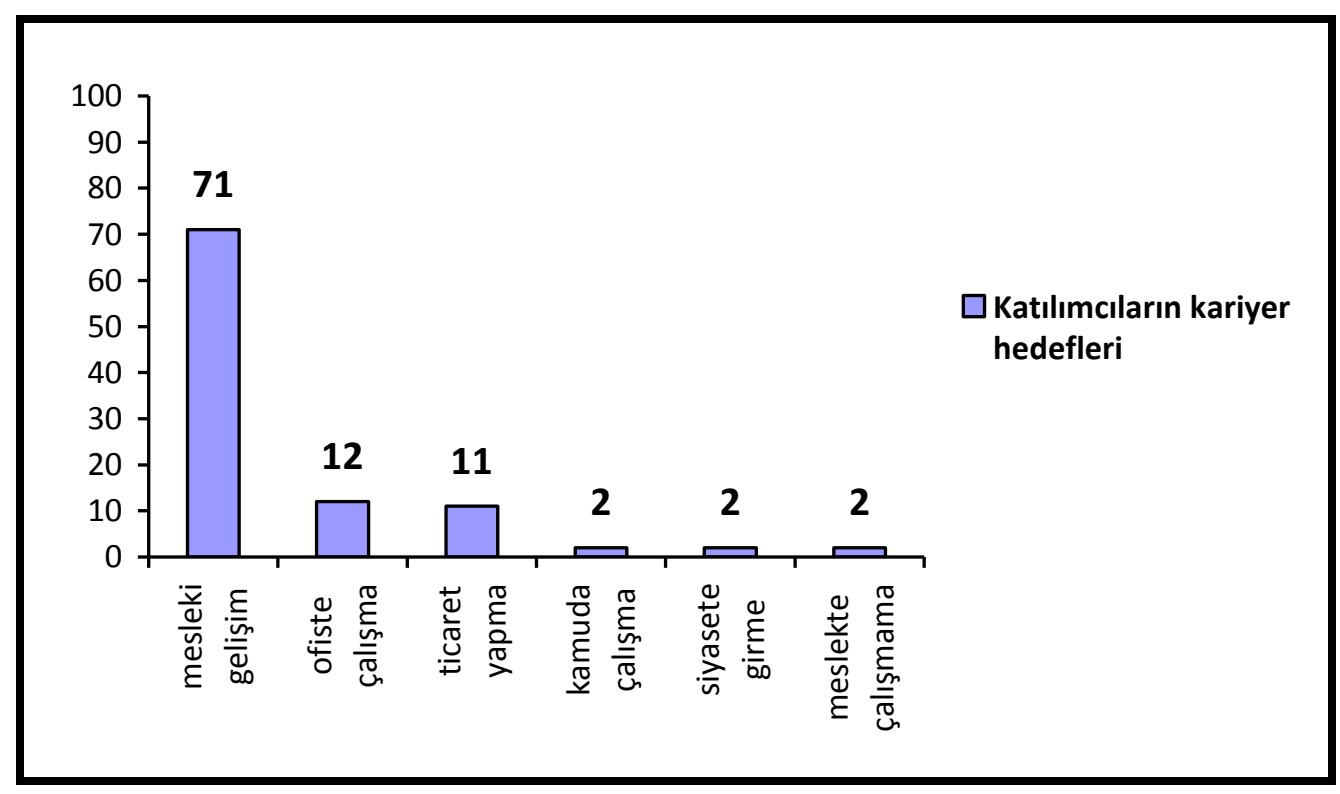

Şekil 6. Katılımcıların kariyer hedefleri.

Katılımcılara mesleki alanda takip ettikleri süreli yayın, sempozyum, seminer, panel vb. etkinlikler sorulmuştur. Alınan cevaplar; katılımcıların \%45'i seminer, sempozyum gibi İMO etkinliklerine katıldıklarını, \%10'u mesleki dergileri takip ettiklerini, \%7'si internet ortamından doküman inceleme yaptıkları, \%38'i hiçbir şey yapmadıkları şeklindedir. Ancak mesleki anlamda gelişim için kendilerinden daha tecrübeli mühendisler ile paylaşımları olduğunu, bir kısmının lisansüstü eğitim ile destek aldıklarını söyleyebiliriz.

Katılıcımlara birlikte çalıştığınız farklı meslek üyeleri ile iletişim bozukluğu, anlaşama mazlık yaşıyor musunuz? sorusuna verilen cevapların \%85'i evet, \%15'i hayır cevabı vermiştir. Evet cevabı verenler genelde farklı disiplinler arası, özellikle mimar ve belediyeler ile mesleki çatışma yaşadıklarını belirtmişlerdir.

Son olarak katılımcılara mezun olduğunuz bölümün ayrıcalıkları ve dezavantajları nelerdir? Bunları ifade eder misiniz şeklindeki sorunun cevabı; bölümün köklü olması, eğitim kalitesinin varlığı olarak avantajlarını, fiziki ve sosyal imkanların yetersizliği, dil eğitimi eksikliği ve teorinin uygulamada tıkandığı yeterli gelmediği şeklinde dezavantajlarını belirtmişlerdir. Bu olumsuzluklara rağmen çok çalışarak eksikliklerini giderip başarılı olduklarını ifade etmişlerdir.

\section{Sonuçlar}

Bireylerin yaşam öyküsünü aile yapısı, kişilerarası etkileşimler, tarihsel zaman, kültürel alt kimlikler, ekonomik nedenler oluşturmaktadır [17]. Bu çalışmada ele alınan bireyin kariyer gelişimi yaşam öyküsünde önemli bir evredir. Bu süreç; küçük yaşlardan başlayıp yaşadığ 1 tecrübeler 1şı̆̆ında geleceğine yönelik planlamaları ve hedeflerine karar verdiği dönemlerdir. Bu çalışma ile katılımcılara gönderilen anket formundaki soruları, kendilerine hiçbir zorlama olmadan tamamen gönüllülük esasına dayalı olarak yanıtlamaları istenmiştir. Elde edilen verilerin analizi ile inşaat mühendisliği bölümü mezunlarının kariyer gelişimlerine ait bakış açıları daha somut hale gelmiştir. 
Kariyer planlama ve gelişimine; özellikle meslek seçiminde ebeveynlerin etkili olduğu daha önceki çalışmalarda belirtilmiştir [18]. Bu çalışma ile de katılımcıların meslek seçimlerinde aile ve çevrelerinde bulunan inşaat sektörü aktörlerinin yönlendirmede etkili olduğu sonucuna varılmıştır. Ancak kariyer gelişiminde aile etkisini ölçmenin; aile yapısında devam eden değişiklikler göz önüne alınarak yapıldığında teknik olarak zor olduğu bilinmektedir [18].

Mezunların kendini tanıma, iş ve meslek bilgisi, mesleki konuları takip etme, kariyer tercihi, planlama ve hedefleri konusunda yetkin oldukları araştırma da görülmüştür. Mezunların orta ve yeterli olarak verdikleri cevaplar birlikte düşünüldügüüde; \%54 oranında inşaat mühendisliği mesleğine ve sektörüne uzak olmadıkları, daha önceden bilgilerinin var olduğu ölçülmüştür.

Geleceğin mühendisleri; çok dil konuşabilen, liderlik vasıfları olan, iyi eğitimli, takım çalışmasına yatkın kişiler olarak tanımlanabilir [19]. Bu tanımdaki yetenekleri ve yetkinliğe haiz mühendislerin varlığı kariyer gelişimleri sürecinin verimli bir şekilde yönetilmesi ile mümkün olacaktır. Kariyer gelişimine hem sosyal hem de iktisadi ve ekonomik faktörlerin etkisi bilinmektedir. Son günlerde dünyanın yaşadığı Covid-19 pandemi salgın süreci birçok alanda oluşan süreksizlikler sebebiyle bireylerin kariyer gelişimlerinde etkili olacağı beklenmektedir. Özellikle; inşaat sektörü gibi insan odaklı, dış çevre koşullarına bağlantılı, çok katılımlı lokomotif vazifesi gören sektörlerin Covid-19 pandemi sürecinden önemli derecede etkilenmesi doğaldır. Bu anlamda kariyer planlaması yapan bireylerin bu süreçte dikkatli olması gerekir. Covid-19 pandemi salgın süreci dünya ülkelerinin ekonomik anlamda sıkıntılara götürmektedir. Dolayısı ile bireylerin mezuniyet sonrası istihdam hedeflerine yönelik gecikmeler, çalışanların mevcut durumlarını koruyabilme, sağlık sorunları vb. nedenler ile kariyer gelişimlerine ait dönemsel duraksamalar olabilir. Dünya çeşitli bedeller ödeyerek bu salgını bertaraf ettiğinde, bireylerin kariyer gelişimlerine olumsuz etki eden faktörler minimuma inecektir. Yapılan çalışmada; anket sorularını karşılayan yedi kritere bağlı elde edilen bulgulardan; mesleki gelişim sürecinin doğru ve verimli olması gerektiğini anlamaktayız. Katılımcıların, belirledikleri kariyer hedeflerine ulaşmada; yabancı dilin, yapılan stajların, bölümün eğitim-öğretim yeterliliğinin, mesleki alan seminerlerinin izlenmesinin olumlu bir etken olduğu tespit edilmiştir. Bu çalışmanın halen eğitim gören mühendis adayları için kariyer planlamaları ve kariyer hedeflerini belirleme konusunda farkındalık yaratacağı ve gelecek çalışmalarda ekonomik ve sosyal çevre açısından Covid-19 pandemi sürecine ait dönemsel kariyer gelişimin incelenmesi yapılabilir.

\section{Teșekkür}

Anket çalışmasında görev alan İnş. Müh. Aslı Yılmaz ve İnş. Müh. Pelinsu Yüzer 'e teşekkür ederim.

\section{Kaynaklar}

[1] Ulaş, Ö., Yıldırım, İ., Kariyer Kararı Verme Yetkinliği Ölçeği'nin Geliştirilmesi, Türk Psikolojik Danışma ve Rehberlik Dergisi, 6(45), 77-90, 2016.

[2] Sarıcı, S.H., Üniversite Öğrencilerinin Kariyer Planlama Faaliyetlerini Demografik Değişkenlere Göre İncelenmesi: Vakıf Üniversitesi Örneği, Yüksek Lisans Tezi, Karatay Üniversitesi, Sosyal Bilimler Enstitüsü, Konya, (2020). 
[3] Joyner, J., Management Skills for Civil Engineer, erişim adresi: https://work.chron.com/management-skills-civil-engineers-5882.html.

[4] Marino, G., Management Skills Crucial for Engineering Success, The American Society of Mechanical Engineers, December 28,2010.

[5] Çivici, T., İnşaat Proje Organizasyonlarında Kişiler Arası Çatışma Çözüm Yaklaşımları ile Kişilik Özellikleri Arasındaki İlişki, Çukurova Üniversitesi Mühendislik Mimarlık Fakültesi Dergisi, 34(3), 195-206, (2019).

[6] Aydınlı, S., Çelik, G.T., Bayram S., Oral, E., İnşaat Mühendisliği Öğrencilerinin Mesleki Beklentileri ve Kariyer Planları, Yükseköğretim Dergisi,10(1), 38-50, (2020)

[7] History and Heritage of Civil Engineering, ASCE, retrieved 8 August 2007.

[8] Griggs, Francis E Jr.,Amos Eaton was Right!, Journal of Professional Issues in Engineering Education and Practice, Vol. 123, No. 1, January 1997, pp. 3034.

[9] ITU. tarihçe,http://insmuh.itu.edu.tr/hakkimizda/tarihce, (02.01.2020).

[10] Üniversitelerimiz, Yükseköğretim Program Atlas1, http://yokatlas.yok.gov.tr/universite.php, (2020).

[11] Uğurlu,P., Devlet ve Vakıf Üniversiteleri İşletme Lisans Öğrencilerinin Kariyer Bilinci ve Kariyer Planlama Konusundaki Farkındalıkları Üzerine Bir Değerlendirme, Yüksek Lisans Tezi, Ufuk Üniversitesi, Sosyal Bilimler Enstitüsü, Ankara, (2020).

[12] Demir, K., İyi Bir Mühendislik Kariyerinin Önündeki 7 Engel, 21.03.2015, https://tr.linkedin.com/pulse/türkiyede-inșaat-mühendisliği-kariyerininönündeki-demir-pmp-ccme, (2020)

[13] Altunışık, R. Coşkun, R. Bayraktaroğlu, S. Yıldırım, E., Sosyal Bilimlerde AraştırmaYöntemleri, Sakarya Yayıncılık, (2010).

[14] Jansen E. \& Chandler G. N., The Psychological contrack between volunteers and not-for-profit organizations: A career perspective, Toward the 21 st century: Challenges For The Voluntary Sector. London Scholl of Economics, (1990).

[15] İMO, Türkiye'de İnşaat Mühendisliği Eğitimine İnşaat Mühendisliği Bölümleri, İnşaat Mühendisliği Öğrencileri, İnşaat Mühendisleri ve İnşaat Sektörüyle Genel Bir Bakış Rapor (2017), http://www.imo.org.tr/resimler/ekutuphane/pdf/13848.pdf

[16] YTÜ, mezun anketi- İnşaat Mühendisliği Bölümündeki Eğitim Öğretim Faaliyetlerinin Mezunlarımıza kazandırdıkları Açısından Değerlendirilmesi, http://www.inm.yildiz.edu.tr/images/files/Mezun_Anketi_sorulari.pdf,(2020)

[17] Karaırmak Ö., Bugay, Ö., Postmodern Diyalog: Öyküsel Psikolojik Danışma, Türk Psikolojik Danışma ve Rehberlik Dergisi. 4(33)24-36, (2010).

[18] C. Chope, R., Qualitatively Assessing Family Influence in Career Decision Making". Journal of Career Assessment. 395-414, (2005).

[19] Pennoni, C.R., Managing Your Career In An Era Of Change, Journal Of Professional Issues In Engineering Education And Practise, July,1996. 